\title{
Work on Job Satisfaction of Employees
}

\author{
Magdalene Peter, S. Fabiyola Kavitha
}

\begin{abstract}
Shopper unwaveringness is a key goal of any relationship, since a satisfied customer is the inside stress of any affiliation; they give close thought to the segments that effect customers' satisfaction. - The data required for study will accumulate through an essential survey. - It fuses supposition of customers on various pieces of customer's wants and buyer devotion as well.
\end{abstract}

Constrained time fight The Royal Enfield advancements seen on electronic and print media are absolutely far off from the Indian culture and perspective. An Indian buyer paying little mind to their compensation level has a fragile corner for shows and culture of India. From this time forward, all associations including business sector pioneers like Royal Enfieldand Bajaj benefit by this lead of customers and structure their ad campaigns recalling India.

The examination has shown that operator and the understudies are the crunch sought after by the specialists. The Royal Enfield is having an energetic interest as the $62 \%$ of the buyers are seen to be underneath the age get-together of 20-30 years sought after by 30-50 years. Addition in customer request response During the assessment it was found that merchants are not satisfying the inquiries of customers in this way prescribed to grow customer question response by sellers. Addition in customer request response During the assessment it was found that dealers are not satisfying the request of customers hence proposed to extend customer question response by merchants.

Keywords : Royal Enfieldand, endeavor, unwaveringness

\section{INTRODUCTION}

\section{Job Satisfaction:}

Shopper unwaveringness is a key goal of any relationship, since a satisfied customer is the inside stress of any affiliation; they give close thought to the segments that effect customers' satisfaction. - The data required for study will accumulate through an essential survey. $\bullet$ It fuses supposition of customers on various pieces of customer's wants and buyer devotion as well. [1],[3],[5]

Constrained time fight The Royal Enfield advancements seen on electronic and print media are absolutely far off from the Indian culture and perspective. An Indian buyer paying little mind to their compensation level has a fragile corner for shows and culture of India. From this time forward, all associations including business sector pioneers like Royal Enfield and Bajaj benefit by this lead of customers and structure their ad campaigns recalling India. [2 ], [4],[6]

The examination has shown that operator and the understudies are the crunch sought after by the specialists. The Royal Enfield is having an energetic interest as the $62 \%$ of the buyers are seen to be underneath the age get-together of 20-30 years sought after by 30-50 years. Addition in customer request response During the assessment it was found that merchants are not satisfying the inquiries of customers in this way prescribed to grow customer question response by sellers. Addition in customer request response During the assessment it was found that dealers are not satisfying the request of customers hence proposed to extend customer question response by merchants. [7],[9],[11]

\section{RESULTS \&DISCUSSION}

Table 1 Satisfaction of canteen facilities

\begin{tabular}{|l|l|l|l|}
\hline SI. No & Level of satisfaction & $\begin{array}{l}\text { No. of } \\
\text { Respondents }\end{array}$ & Percentage \\
\hline 1 & Highly satisfied & 12 & 13 \\
\hline 2 & Satisfied & 80 & 87 \\
\hline 3 & Neutral & 0 & 0 \\
\hline 4 & Dissatisfied & 0 & 0 \\
\hline 5 & Highly dissatisfied & 0 & 0 \\
\hline & & 92 & 100 \\
\hline
\end{tabular}

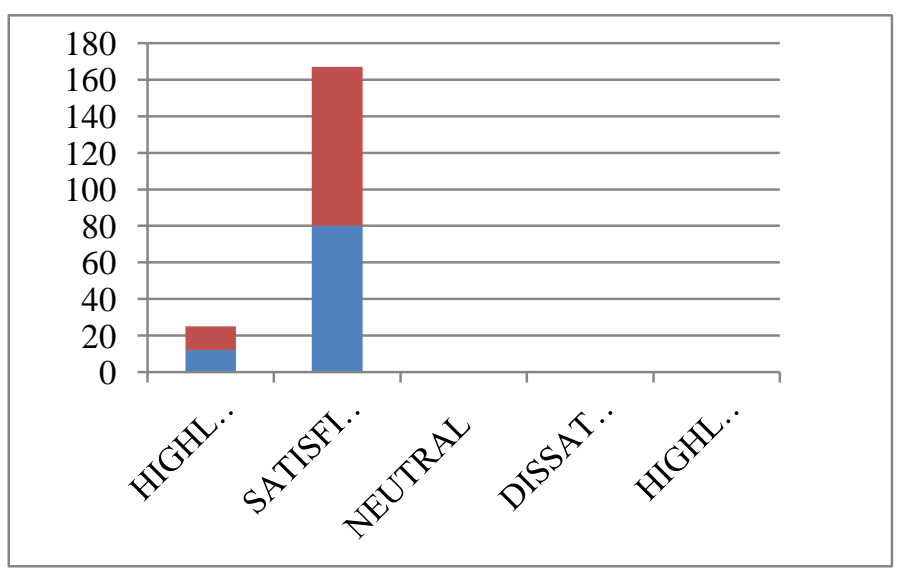

Revised Manuscript Received on July 22, 2019.

Magdalene Peter ,Assistant Professor Department of MBA,Bharath institute of Higher Education \& Research,Tamilnadu,India,Email: magdalene.bsb@gmail.com

Dr.S.Fabiyola Kavitha, Associate Professor,Department of MBA,Bharath institute of Higher Education \& Research,Tamilnadu,India, Email: fabiolakavitha@gmail.com 
TABle 2 SATISFACTION OF MEDICAL FACILITIES

\begin{tabular}{|l|l|l|l|}
\hline SI. No & Level of satisfaction & No. of Respondents & Percentage \\
\hline 1 & Strongly Agree & 44 & 48 \\
\hline 2 & Agree & 40 & 43 \\
\hline 3 & Moderate & 8 & 9 \\
\hline 4 & Disagree & 0 & 0 \\
\hline 5 & Strongly Disagree & 0 & 0 \\
\hline & & 92 & 100 \\
\hline
\end{tabular}

From the table it indicates that 48 percent of employees strongly agree with the Medical facilities and 43 percent of employees agree and 9 percent of employees are moderate on the medical facilities. [8],[ 10],[12]

\section{fig: 2 Satisfaction of canteen facilities}

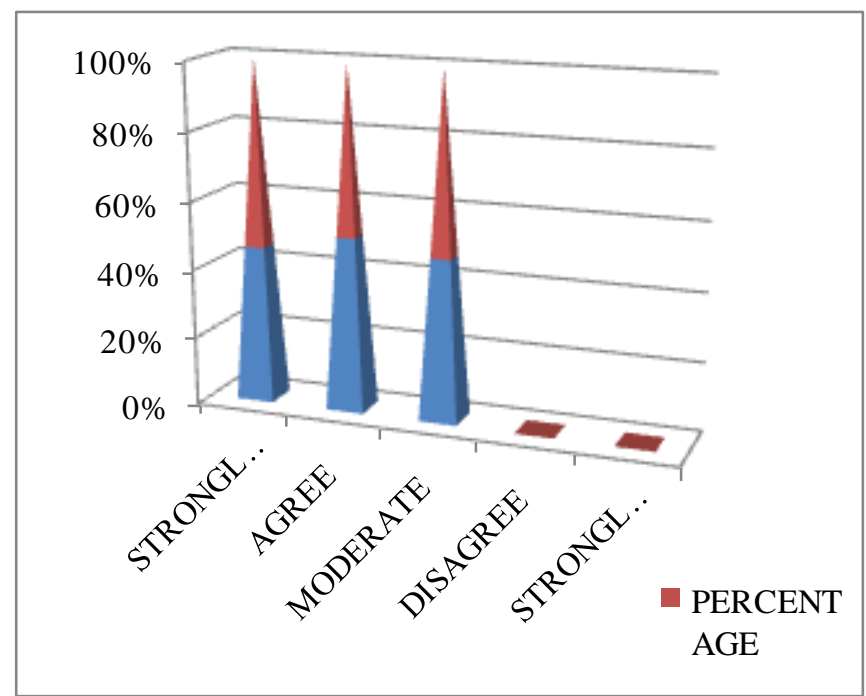

TABle 3 SATISFACTION OF HeALTh \& SAFETY WORKING CONDITION

\begin{tabular}{l|l|l|l|}
\hline SI. No & Level of satisfaction & $\begin{array}{l}\text { No. of } \\
\text { Respondents }\end{array}$ & Percentage \\
\hline 1 & Highly satisfied & 44 & 52 \\
\hline 2 & Satisfied & 40 & 44 \\
\hline 3 & Neutral & 4 & 4 \\
\hline 4 & Dissatisfied & 0 & 0 \\
\hline 5 & Highly dis satisfied & 0 & 0 \\
\hline & & 88 & 100 \\
\hline
\end{tabular}

From the table it indicates that 52percent of employees are highly satisfied with the Safety and healthy working conditions and 44percent of employees are satisfied, 4percent of employees are neutral with the safety and healthy working conditions.

Fig 3 Satisfaction of Health \& safety working Condition

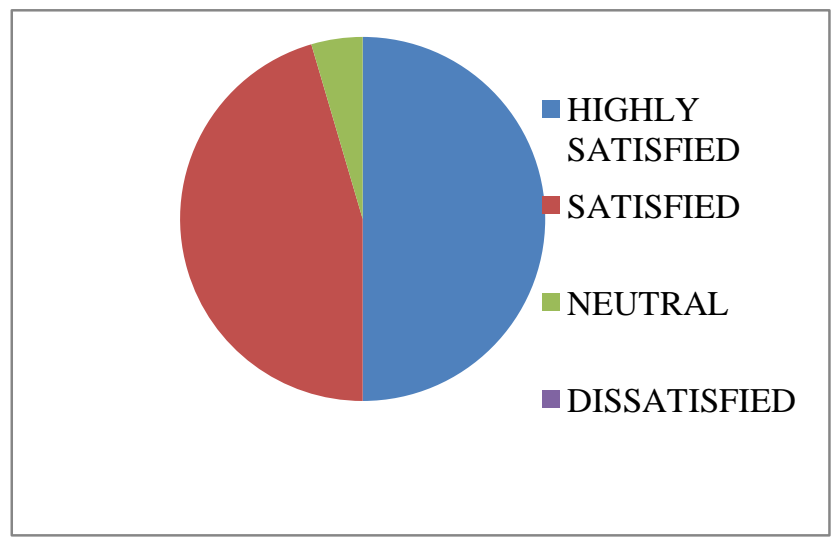

TABLE 4 SATISFACTION ON THE CURRENT JOB

\begin{tabular}{|l|l|l|l|}
\hline SI. No & Level of satisfaction & $\begin{array}{l}\text { No. of } \\
\text { Respondents }\end{array}$ & Percentage \\
\hline 1 & Highly satisfied & 42 & 46 \\
\hline 2 & Satisfied & 44 & 48 \\
\hline 3 & Neutral & 6 & 6 \\
\hline 4 & Dissatisfied & 0 & 0 \\
\hline 5 & Highly dissatisfied & 0 & 0 \\
\hline & & 92 & 100 \\
\hline
\end{tabular}

From the table it indicates that 46percent of employees are highly satisfied with their current job and 48percent of employees are satisfied, and 6percent are neutral with their current job. [13], [15] ,[ 17]

CHART 5 satisfaction on the current job

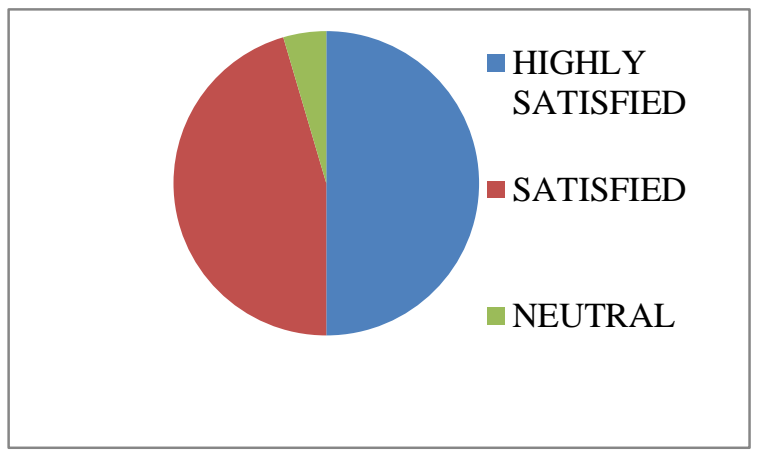

Table 6:level of satisfaction

\begin{tabular}{|l|l|l|l|}
\hline SI. No & Level of satisfaction & $\begin{array}{l}\text { No. of } \\
\text { Respondents }\end{array}$ & Percentage \\
\hline 1 & Highly satisfied & 42 & 46 \\
\hline 2 & Satisfied & 44 & 48 \\
\hline 3 & Neutral & 6 & 6 \\
\hline 4 & Dissatisfied & 0 & 0 \\
\hline 5 & Highly dis satisfied & 0 & 0 \\
\hline & & 92 & 100 \\
\hline
\end{tabular}


From the table it indicates that 46percent of employees are highly satisfied with their current job and 48percent of employees are satisfied, and 6percent are neutral with their current job. [14],[16], [18]

Fig 6 satisfaction on the current job

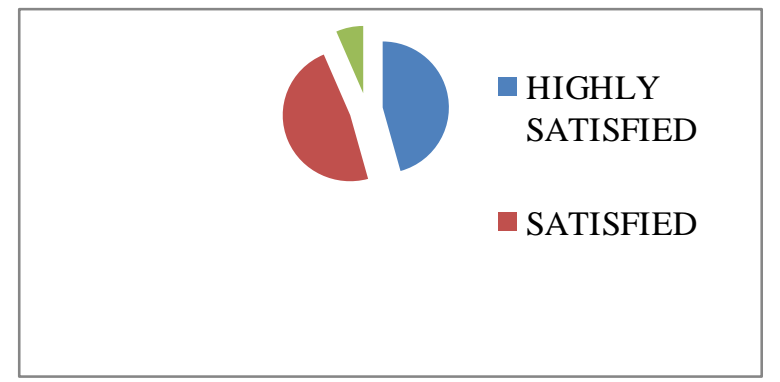

TABLE 7 Satisfaction of Earned Leave With Pay

\begin{tabular}{|l|l|l|l|}
\hline SI. No & Level of satisfaction & $\begin{array}{l}\text { No. of } \\
\text { Respondents }\end{array}$ & Percentage \\
\hline 1 & Strongly agree & 44 & 52 \\
\hline 2 & Agree & 36 & 39 \\
\hline 3 & Moderate & 8 & 9 \\
\hline 4 & Disagres & 0 & 0 \\
\hline 5 & Strongly disagree & 0 & 0 \\
\hline & & 88 & 100 \\
\hline
\end{tabular}

From the table it indicates that 52percent of employees are highly satisfied with their earned leave with pay and 39 percent of employees are satisfied, and 9percent of the employees are moderate on their earned leave. [31],[33]

TABLE 8 SATISFACTION OF EARNED LEAVE WITH PAY

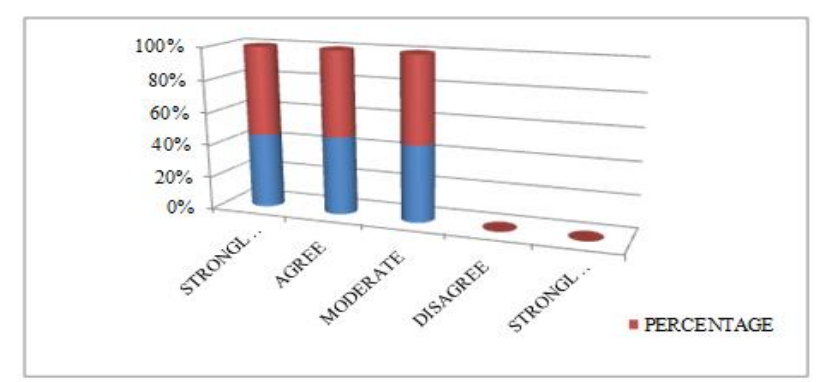

fig 9 Satisfaction of Salary package

\begin{tabular}{|l|l|l|l|}
\hline SI. No & Level of satisfaction & $\begin{array}{l}\text { No. of } \\
\text { Respondents }\end{array}$ & Percentage \\
\hline 1 & Highly satisfied & 28 & 30 \\
\hline 2 & Satisfied & 56 & 61 \\
\hline 3 & Neutral & 8 & 9 \\
\hline 4 & Dissatisfied & 0 & 0 \\
\hline 5 & Highly dis satisfied & 0 & 0 \\
\hline & & 92 & 100 \\
\hline
\end{tabular}

From the table it indicates that 30percent of employees are highly satisfied with the Salary package, 61percent of employees are satisfied, and 9percent are neutral with their salary package. [19],[21],[23]

Fig 9 Satisfaction of Salary Package

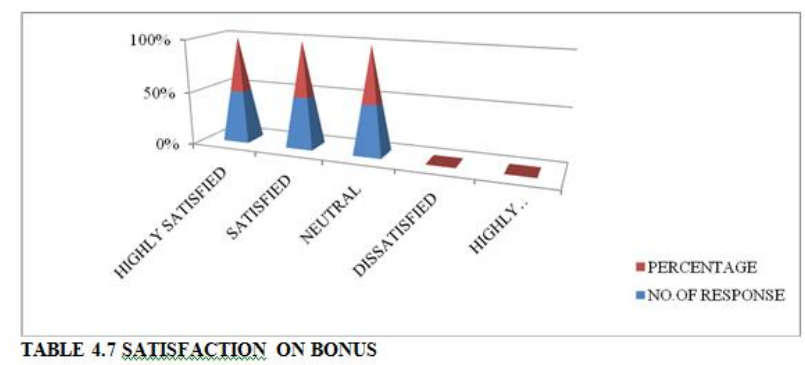

Table 9 Satisfaction of Salary Package

\begin{tabular}{|l|l|l|l|}
\hline SI. No & $\begin{array}{l}\text { Level of } \\
\text { satisfaction }\end{array}$ & $\begin{array}{l}\text { No. of } \\
\text { Respondents }\end{array}$ & Percentage \\
\hline 1 & Strongly agree & 38 & 41 \\
\hline 2 & Agree & 44 & 48 \\
\hline 3 & Moderate & 8 & 9 \\
\hline 4 & Disagree & 2 & 2 \\
\hline 5 & Strongly disagree & 0 & 0 \\
\hline & & 92 & 100 \\
\hline
\end{tabular}

From the table it indicates that 41percent of employees are highly satisfied with the bonus and 48percent of employees are satisfied, 9percent of employees are neutral and 2percent of employees are dissatisfied, and 0percent of employees are highly dissatisfied with the bonus. [20],[22], [24]

Fig 10 Satisfaction on Bonus

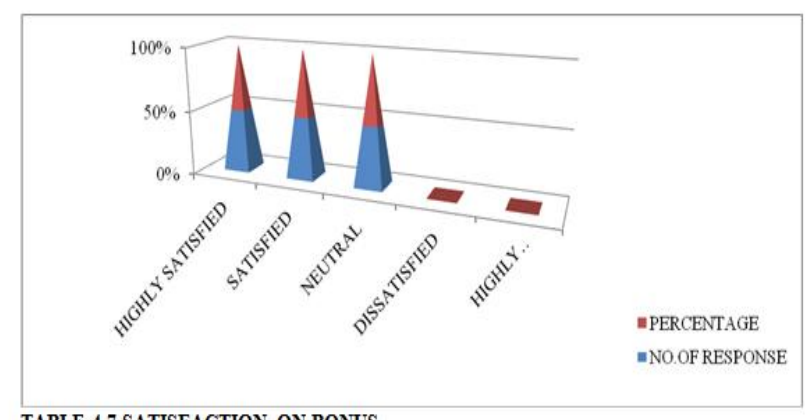

TABLE 4.7 SATISFACTION ON BONUS

They also want a constant feeling of well being, demand better work \&family life balance, and look to the organization for fulfilling even their community needs. These highlighted expectations result in dissatisfaction, and finds true job happiness remains an un 
filled dreams all the job hopping not withstand.Thus the overall job satisfaction of employees at Lucas-TVS Limited is very high. The employees at Lucas-TVS Limited have a very good high regards and respect towards the company's image and future of the organization[25],[27],[29]

\section{CONCLUSION}

The examination has shown that operator and the understudies are the crunch sought after by the specialists. The royal enfield is having an energetic interest as the $62 \%$ of the buyers are seen to be underneath the age get-together of 20-30 years sought after by 30-50 years. Addition in customer request response during the assessment it was found that merchants are not satisfying the inquiries of customers in this way prescribed to grow customer question response by sellers. Addition in customer request response during the assessment it was found that dealers are not satisfying the request of customers hence proposed to extend customer question response by merchants[26],[28],[30]

\section{REFERENCES}

1) BharthVajan R., Ramachandran S.,Psychographic dimensions of training,2016,International Journal of Pharmacy and Technology,V-8,I-4,P-23727-23729

2) Balakrishnan P., Bharthvajan R.,A study on human resource planning in hospitals in Chennai City,2014,International Journal of Applied Engineering Research,V-9,I-22,P-7503-7507

3) Priyadarsini P., Bharthvajan R.,Role of emotional intelligence training programme in reducing the stress of the nurses,2014,International Journal of Applied Engineering Research,V-9,I-22,P-7411-7421

4) Kerinab Beenu G., Bharthvajan R.,Empirical analysis on the cosmetic buying behavior of young women in South India,2014,International Journal of Applied Engineering Research,V-9,I-22,P-7361-7366

5) Balakrishnan P., Bharthvajan R.,Whistling in the wind,2014,International Journal of Applied Engineering Research,V-9,I-22,P-7586-7593

6) Krishnan B., Peter M.,Health hazards of Indian Bpo employee-an alarming issue,2014,International Journal of Applied Engineering Research,V-9,I-22,P-7336-7341

7) Kerinab Beenu G.H., Peter M.,Role of insurance in economic development,2014,International Journal of Applied Engineering Research,V-9,I-22,P-7532-7539

8) Balakrishnan P., Peter M., Priyadarsini P.,Efficiency of safety measures for wellbeing of employees in manufacturing industry,2014,International Journal of Applied Engineering Research,V-9,I-22,P-7376-7382

9) Anbarasi M., Praveen Kumar S.,Online sales promotions of herbal products and its effectiveness towards tanisha.com,2019,Indian Journal of Public Health Research and Development,V-10,I-1,P-195-200

10) Anbarasi M., Praveen Kumar S.,Various online marketing and promotions strategies to improve the validation towards the organic products in the pharmaceutical sectors,2019,Indian Journal of Public Health Research and Development,V-10,I-1,P-263-269

11) Loganathan R., Praveen Kumar S.,Grievance handling a key factor for solving issues of employees in an organization,2014,International Journal of Applied Engineering Research,V-9,I-22,P-7483-7491

12) Loganathan R., Praveen Kumar S.,Study on preference of private label brands in super and Hypermarkets,2014,International Journal of Applied Engineering Research,V-9,I-22,P-7327-7335

13) Smitha M., Praveen Kumar S.,Understanding stress and its managementamong the nurses in Chennai city,2014,International Journal of Applied Engineering Research,V-9,I-22,P-7560-7565

14) Kerinab Beenu G.H., Praveen Kumar S.,A study on the investment behavior of Chennai investors in mutual fund schemes,2014,International Journal of Applied Engineering Research,V-9,I-22,P-7520-7525

15) Loganathan R., Praveen Kumar S.,Retention strategies key for organizational productivity,2014,International Journal of Applied Engineering Research,V-9,I-22,P-7443-7447

16) Pavithra J., Ganesan M., Brindha G.,State wise analysis of microfinance sector in India,2016,International Journal of Pharmacy and Technology,V-8,I-4,P-23417-23432

17) Pavithra J., Ganesan M.,A comparative study on microfinance in India and abroad,2016,International Journal of Applied Business and Economic Research,V-14,I-8,P-5471-5476
18) Pavithra J., Ganesan M.,A study on awareness and impact of micro-financial schemes,2016,International Journal of Applied Business and Economic Research,V-14,I-8,P-5449-5460

19) Senthilmurugan P., Pavithra J.,Consumer preference towards organised retailing with reference to Big Bazaar,2014,International Journal of Applied Engineering Research,V-9,I-22,P-7469-7475

20) Senthilmurugan P., Pavithra J.,Implication of social media marketing in growing healthcare industry,2014,International Journal of Applied Engineering Research,V-9,I-22,P-7448-7456

21) Loganathan R., Pavithra J.,Consumer perception towards private label brand over other brands in super markets and hypermarkets,2014,International Journal of Applied Engineering Research,V-9,I-22,P-7355-7360

22) Kerinab Beenu G., Pavithra J.,Tradeâ€"off between liquidity and profitability in logistics industry,2014,International Journal of Applied Engineering Research,V-9,I-22,P-7398-7401

23) Kerinab Beenu G., Pavithra J.,A study on the prospective consumerâ€ ${ }^{\mathrm{TM}_{S}}$ perception towards utility cars in Chennai city,2014,International Journal of Applied Engineering Research,V-9,I-22,P-7526-7531

24) Pavithra J., Dilli Babu P., Ambuli T.V.,A study on budgetary control at Maruti Service Masters, Chennai,2014,International Journal of Applied Business and Economic Research,V-12,I-2,P-151-161

25) Pavithra J., Dilli Babu P., Ambuli T.V.,A study on customer satisfaction of retro Garments Pvt Ltd, Chennai,2014,International Journal of Applied Business and Economic Research,V-12,I-2,P-381-391

26) Kerinab Beenu G.H., Pavithra J., Senthilmurugan P.,A study on the influence of promotional activities for TATA ARIA among consumers in Chennai,2014,International Journal of Applied Engineering Research,V-9,I-22,P-7572-7578

27) Vijayaragavan S.P.,An investigative expert that's general FBG sensors,International Journal of Mechanical Engineering and Technology,V-8,I-8,PP-1500-1505,Y-2017

28) Vijayaragavan S.P.,Equalization routing protocol for Wi-Fi sensor strategy,International Journal of Mechanical Engineering and Technology,V-8,I-8,PP-1662-1666,Y-2017

29) Karthik B., Kiran Kumar T.V.U., Vijayaragavan P., Bharath Kumaran E.,Design of a digital PLL using 0.35 $\hat{\mathrm{I}}^{1} / 4 \mathrm{~m}$ CMOS technology,Middle East Journal of Scientific Research,V-18,I-12,PP-1803-1806,Y-2013

30) Kanniga E., Selvaramarathnam K., Sundararajan M.,Kandigital bike operating system,Middle - East Journal of Scientific Research,V

31) Jasmin M., Vigneshwaran T., Beulah Hemalatha S.,Design of power aware on chip embedded memory based FSM encoding in FPGA,International Journal of Applied Engineering Research,V-10,I-2,PP-4487-4496,Y-2015

32) Jasmin M.,Optimization techniques for low power VLSI circuits,Middle East Journal of Scientific Research,V-20,I-9,PP-1082-1087,Y-2014

33) Jasmin M., Vigneswaran T.,Fuzzy controller for error control of on - Chip communication,2017 International Conference on Algorithms, Methodology, Models and Applications in Emerging Technologies, ICAMMAET 2017,V-2017-January,I-,PP-1-5,Y-2017

\section{AUTHORS PROFILE}

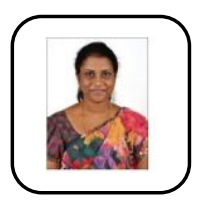

Magdalene Peter ,Assistant Professor Department of MBA,Bharath institute of Higher Education \& magdalene.bsb@gmail.com Research,Tamilnadu,India,Email:

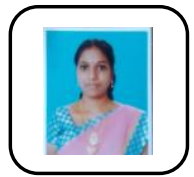

Dr.S.Fabiyola Kavitha, Associate Professor,Department of MBA,Bharath institute of Higher Education \& Research,Tamilnadu,India 